\title{
Instructor and student experiences with open textbooks, from the California open online library for education (Cool4Ed)
}

\author{
Ozgur Ozdemir ${ }^{1} \cdot$ Christina Hendricks $^{2}$ (D)
}

Published online: 7 March 2017

(C) The Author(s) 2017. This article is published with open access at Springerlink.com

\begin{abstract}
Open textbooks are similar to traditional textbooks except that they are free of cost and licensed to allow revision and reuse. Adopting open textbooks for higher education courses is a way to address the growing costs of traditional textbooks that lead some students to be unable to access them, and to allow instructors to tailor the books to their own particular course context. Several empirical studies over the last few years have shown that open textbooks have the potential to increase student access to course readings without sacrificing quality. Adding to these results, this study focused on data from a new source: over fifty e-portfolios written by faculty about the use of open textbooks in their courses in several college and university systems in the state of California. We studied instructor's motivations for adopting an open textbook for their courses, the cost savings to students as a result of this adoption, the impact of assigning open textbooks on student learning outcomes and withdrawal rates, and other benefits and drawbacks of open textbooks. Faculty reported that cost savings was the most important motivation for adopting open textbooks, and that students most often reported this as what they appreciated about open textbooks. The vast majority of faculty also reported that the quality of the textbooks was as good or better than that of traditional textbooks, and that students did as well or better in terms of learning outcomes and withdrawal rates compared to when the same courses were run with traditional textbooks.
\end{abstract}

Christina Hendricks

c.hendricks@ubc.ca

Ozgur Ozdemir oozdemir@indiana.edu

1 Indiana University, Bloomington, IN, USA

2 University of British Columbia-Vancouver, Vancouver, BC, Canada 
Keywords Open education · Open textbooks · Open educational resources

\section{Introduction}

The price of college textbooks has continued to increase over the past decades. According to the federation of student Public Interest Research Groups, an 82\% increase in new college textbook prices was observed between the years 2002 and 2012 (Student PIRGs 2014). This increase is approximately three times the rate of inflation. The same report estimated that college students invest an average of $\$ 1200$ per year on textbooks and course supplies.

The high cost of textbooks impedes their wide adoption among students. The Advisory Committee on Student Financial Assistance (2007) stated that financial obstacles students experience preclude them from purchasing required textbooks. Student PIRGs (2014) found that $65 \%$ of 2039 college students in more than 150 campuses decided against purchasing a textbook during the fall of 2013 because of costs. In Florida, survey results over 22,000 post-secondary students showed that $67 \%$ of them did not purchase a required textbook because of its high price (Florida Virtual Campus 2016).

Open educational resources (OER) provide a solution for eliminating monetary barriers to purchasing textbooks. As a subset of OER, high quality free and open textbooks have the potential to decrease student expenditures significantly. Hilton (2016) synthesized sixteen studies relating to effectiveness and perceptions of OER, and found that in general, students and faculty find them to be of equal or better quality than traditional textbooks and that students perform just as well in their classes when using OER as traditional textbooks.

More empirical work is needed regarding the experiences of teachers and students using open textbooks, to show that they can provide equal pedagogical value at low or no cost to students. This study adds to the existing literature by analyzing a new set of data: a collection of faculty reports on their use of open textbooks, from the California Open Online Library for Education (Cool 4 Ed: http://cool4ed.org). Using this qualitative and quantitative data we explore instructors' motivations for adopting open textbooks, potential cost savings for students, students' feedback on open textbooks, faculty and student perception of whether open textbook adoption improves student learning, and other benefits and drawbacks of open textbook use.

\section{Literature review}

Open textbooks are defined briefly as "faculty-written, peer-reviewed textbooks that are published under an open license-meaning that they are available free online, they are free to download, and print copies are available at $\$ 10-40$, or approximately the cost of printing" (Student PIRGs 2015, p. 9). The open licenses 
of such textbooks usually also allow for revision-for adding, subtracting or changing the books to customize them for particular courses. Open textbook implementation, particularly in higher education, attempts to offer an effective solution to some of the financial issues faced by college students (Hilton and Wiley 2011). A growing number of faculty and students are using open textbooks due to their accessibility, customizability, and high quality.

The efforts to provide students free, open textbooks enables the educational community to experience substantial cost savings (Allen 2010) and increase access to higher education (Frydenberg and Matkin 2007; Seidel 2009). Bliss et al. (2013) carried out a study in order to explore community college teachers' and students' perceptions of open textbooks in which eight community colleges, 58 teachers and 490 students participated. Results showed that both teachers and students observed a nearly $80 \%$ reduction in the cost of textbooks. Bliss et al. (2013) also reported that more than $20 \%$ of faculty mentioned that digital open textbooks bring advantages to students in terms of accessibility. Faculty members stated that having online access to the textbook even before the first day of class helped students progress faster and come to class well prepared. When participants were asked about the quality of open textbooks, $89 \%$ of teachers and $94 \%$ of students perceived that open textbooks are equal to or better in quality than traditional textbooks they had used in the past.

Wiley and Green (2012) noted that the amount of money college students pay for traditional textbooks is " $26 \%$ of the cost of tuition at a public, four-year university" (p. 83). Furthermore, in some community college contexts textbooks are more expensive than the tuition (Petrides et al. 2011). Petrides et al. (2011) employed surveys, interviews and focus groups in order to gather data from faculty and students who used the open Collaborative Statistics textbook in their classes at a community college. Results of interviews and focus groups with 31 faculty members demonstrated that "cost reduction for students was the most significant factor influencing faculty adoption of open textbooks" (p. 43). Other contributing factors to faculty decisions for open textbook adoption and use were content quality and ease of use of open textbooks (Petrides et al. 2011). Recommendation of colleagues, personal relationships with open textbook authors and peer reviews of open textbooks impacted faculty perceptions of content quality. When it comes to ease of use faculty referred to portability of open textbooks and integration of new resources into existing course materials. Students' responses to a survey highlighted the free of cost feature as the primary advantage of using the digital version of the open Collaborative Statistics textbook, though portability and ease of use emerged as other significant factors for students.

According to Feldstein et al. (2012), internal survey results at the Virginia State University School of Business demonstrated that less than half (47\%) of the students purchased textbooks for their classes. The same survey reported that students mostly referred to the affordability problem as a main reason for not purchasing textbooks. To address this issue, open textbooks in different formats including PDF, MOBI, ePub, and MP3 were provided to students through the online Flat World Knowledge (FWK) platform in the School of Business at VSU during the academic year 2010-2011. Tracking students' digital behavior in the online FWK platform revealed that $85 \%$ of the students downloaded either full textbooks or chapters of 
textbooks in various formats, which yielded greater access to learning materials than when the students were asked to purchase commercial textbooks. Moreover, researchers discovered that "students in courses that used FWK textbooks tended to have higher grades and lower failing and withdrawal rates than those in courses that did not use FWK texts" (Feldstein et al. 2012, p. 7). Findings on student outcomes encouraged researchers to claim that greater access to course materials might contribute to improvement in student learning.

Drawing on this literature, this study investigated students' and instructors' experiences of open textbooks. Specifically, we focused on faculty reports on their use of open textbooks on the California Open Online Library for Education (Cool 4 Ed), the vast majority of whom work in three postsecondary systems in California: The University of California system, the California State University system, and the California Community College system. The state of California has funded the Cool $4 \mathrm{Ed}$ project in an effort to help college and university students save money on books, and our study provides data from 50 faculty members who have adopted open textbooks, showing that students have been able to save money while still getting (in the vast majority of cases) the same or better quality teaching materials.

This study complements a recently-published report by the California OER Council (2016), which provides data from focus groups and surveys of faculty and students who used open textbooks in the University of California system, the California State University system, and the California Community College system. Most of the faculty reported that they believed the quality of the open textbook or other OER used was high: "For the most part, faculty felt that the OER materials were thorough and complete and that students learned as well with the OER materials as with the traditional textbook for the class" (p. 21). In their survey of 351 students who were assigned open textbooks or other OER, 89\% of them reported that the quality of the materials was as good or better than that of traditional textbooks they had used in the past. Our research differs in that we looked exclusively at the faculty e-portfolios on the Cool $4 \mathrm{Ed}$ website, but together the 2016 California OER Council report and our research provide a useful picture of the results of the California OER initiative so far.

\section{Context of the study}

Many undergraduate students in California experience significant financial stress when attending college, and some of this can be offset by reducing textbook costs. The average cost of tuition and fees in the University of California system in 2015-2016, averaging over all campuses, was over $\$ 13,000$ (UC remains affordable for undergraduates 2015). UC reports that in Fall 2014, over 50\% of undergraduate students graduated with student loans (UC's affordability report 2015), and since Fall of 2010, the percentage of students in the UC system who receive Pell Grants ${ }^{1}$ has been between 40 and $42 \%$ (UC quick facts at a glance 2015). In the California State University system, as of April 2016, the cost for

\footnotetext{
${ }^{1}$ The Pell Grants program in the United States provides grants to post-secondary students on the basis of financial need. See http://www2.ed.gov/programs/fpg/index.html.
} 
tuition and fees, averaged across all the CSU campuses, was over $\$ 6700$ per year (FAQ-Costs 2015). In addition, $80 \%$ of students in the California State University system received financial aid of some kind during the 2014-2015 academic year (Student Costs 2016). Students attending one of California Community Colleges (CCC) pay about $\$ 1100$ for tuition per year (College costs 2015). Since the College Board estimates average textbook costs for U.S. students in 2015-2016 to be around \$1300 (Average estimated undergraduate budgets 2015), this means that for students in the CCC system, textbooks may cost more than tuition. According to a 2015 survey of nearly 12,000 students at 22 California Community Colleges, paying for textbooks is a serious source of concern: "a couple of books can already be a whole paycheck," one student reports (Cochrane and Szabo-Kubitz 2016, p. 9). The same report noted that of the financial aid recipients who responded to the survey, $32 \%$ said that when they can't afford textbooks, they try to succeed in classes without them, and $27 \%$ said they drop out of one or more classes.

The present study analyzed over 50 faculty reports on the use of open textbooks or other open educational resources, posted on the California Open Online Library for Education website (Cool $4 \mathrm{Ed}$ : http://cool4ed.org). The Cool $4 \mathrm{Ed}$ site was created as part of a mandate from the California state legislature in 2013, focused on helping students afford college by reducing their costs for textbooks and other educational resources. The 2013 legislation instructed the California State University system (CSU), the University of California system (UC), and the California Community Colleges (CCC) to create the California Open Education Resource Council. The Council's mandate included choosing "up to 50 lower division courses in the public postsecondary segments to target the development and acquisition of digital, open source textbooks and materials" and administering a peer review process for open textbooks and other OER (Duties of California OER Council Members 2014, para. 6).

The Cool 4 Ed site includes, among other things: lists of open textbooks and other OER for various disciplines; faculty reviews of open textbooks; a list of first and second year courses in California public postsecondary institutions that are highly-enrolled, along with suggested open textbooks; and a set of faculty showcases featuring information on their use of open textbooks in courses. The textbooks chosen for review on the site fulfilled the following criteria listed on the Cool 4 Ed website:

(1) Creative Commons license (CC-BY), if possible; (2) free or low cost (\$30 or less); (3) able to be re-mixed, if possible ...; (4) updated regularly; (5) offered in at least 2 different formats (e.g., online/pdf); and (6) maintained in an easily accessible and sustainable environment with a persistent URL. (eTextbook Reviews 2014).

Faculty from the three California public postsecondary institution systems involved in the project (CSU, UC, CCC) applied to do peer reviews of textbooks, and received a stipend for completing them. 


\section{Methods}

This research focused on the faculty showcases section of the Cool 4 Ed site (http:// cool4ed.org/facultyshowcase.html), which features e-portfolios of faculty members who have adopted open textbooks or other OER. Each faculty showcase page has four sections: (1) About the textbook: description of the textbook adopted, formats, supplemental resources, peer reviews, cost savings, accessibility and diversity information, and license for the book; (2) About the course: course description, learning objectives, curricular changes made as a result of adopting an open textbook, impact on teaching and learning, sample assignments and syllabus; (3) About the open textbook adoption: the process and motivations for adopting an open textbook, how students access the textbook, student feedback and/or participation; and (4) Faculty bio.

We analyzed 51 faculty e-portfolios representing 30 postsecondary institutions, the vast majority of them in California. The faculty e-portfolios are broken down into disciplinary areas (the numbers list how many portfolios are in each category) (Table 1).

Most of the faculty adopted an open textbook to replace a traditional textbook. For the rest, five used open textbooks or OER as supplements to traditional textbooks students still had to purchase, three used a variety of free online texts and resources instead of a textbook, and one used a low-cost trade paperback plus OER instead of a textbook.

We used content analysis to analyze the qualitative data in the e-portfolios. Content analysis is a technique for coding of raw data in order to create categories that help describe the meaning of communicated materials such as written, spoken or visual documents (Merriam 2009). Open coding strategy was employed to determine the categories used to code the data: the categories emerged from reading through the narratives in the e-portfolios themselves and determining patterns.

Table 1 Number of faculty e-portfolios based on disciplinary areas

\begin{tabular}{lc}
\hline Disciplinary areas & $\begin{array}{c}\text { Number of } \\
\text { e-portfolios }\end{array}$ \\
\hline $\begin{array}{l}\text { Humanities (including history, literature, languages, communication, art history, } \\
\text { and film) }\end{array}$ & 20 \\
Science and technology (including biology, chemistry, physics, and more) & 10 \\
Social science (including psychology, sociology and social work) & 8 \\
Math and statistics & 6 \\
Economics (which the Cool 4 Ed site lists under "business") & 4 \\
Business & 2 \\
Education & 1 \\
\hline
\end{tabular}


Our research questions for the present study were as follows:

1. What common motivations did faculty report for adopting an open textbook or other OER?

2. What were the cost savings for students when these faculty adopted an open textbook for their courses?

3. What was the attitude of students towards the open textbooks adopted?

4. What impact did the open textbooks have on student learning and retention?

5. What other benefits and drawbacks did faculty report in adopting open textbooks?

\section{Results}

\section{Research question 1: What common motivations did faculty report for adopting an open textbook or other OER?}

Content analysis of 51 online portfolios belonging to faculty revealed four common motivating factors for adopting open textbooks in their classes: cost savings, accessibility, content, and repurposing, as can be seen in Table 2. While faculty most frequently referred to cost savings as their motivation to utilize an open textbook, the other three motivations-laccessibility, content and repurposingwere emphasized less than cost savings but were still motivating factors in the adoption process. These will be discussed in the following sections.

\section{Cost savings}

In total, $41(80 \%)$ of the 51 faculty stressed that reducing the cost of education for college students was their priority. While digital open textbooks in different formats are freely accessible, students might need to pay the cost of printing if they would like to acquire printed copies. In both cases, faculty indicated that a significant amount of reduction in the cost of textbooks is possible. As one psychology professor put it, "My main motivation to adopt an open textbook was to reduce the textbook cost for students and to provide more access to courses which are cost prohibitive for some students solely due to the cost of the required text."

Table 2 Faculty motivations for adopting an open textbook or other OER

\begin{tabular}{lc}
\hline Motivators & Number $(\%)$ \\
\hline Cost savings & $41(80 \%)$ \\
Content & $22(44 \%)$ \\
Repurposing & $12(24 \%)$ \\
Accessibility & $11(20 \%)$ \\
\hline
\end{tabular}

$\mathrm{n}=51$ 


\section{Accessibility}

According to faculty, generally two types of accessibility were prominent during their open textbook adoption process. First, offering students free textbooks makes them more accessible financially. A social science professor stated, "my goal with the open textbook adoption program was to reduce textbook costs for students and to ensure that all students had access to course materials for our in-class discussions." Several faculty members mentioned the pedagogical value of students having access to the textbooks from day one (rather than waiting for backordered books, for example). This means they were more prepared during class because they had read the text. Second, faculty underscored that providing students both digitized and printed copies of open textbooks helped increase accessibility to course textbooks and satisfy different student preferences for textbook types. Furthermore, according to faculty, variety in digital textbook formats such as PDF, online, EPUB, and iBook also contributed to improving accessibility. Indeed, $11(22 \%)$ of the total 51 faculty specifically highlighted that allowing students flexibility in accessing open textbooks through different formats were their motivations.

\section{Content}

Faculty were not only concerned with costs. In their remarks they also discussed quality, relevancy, and currency of content as motivating factors for adopting an open textbook. In fact, $22(44 \%)$ of the total 51 study participants pointed out that those features of the content encouraged them to forgo traditional textbooks in favor of free, open textbooks, along with cost savings. For instance, one statistics instructor stated, "my main motivation is to save my students money without compromising on the quality of the text. Happily, this dual purpose is served extremely well by using this [open statistics] textbook." As another example, the following comment on quality and cost-effectiveness of an open textbook was provided by a social science professor: "The major motivation in adopting this [open] textbook was to save students money, without sacrificing the quality of content."

Faculty also found that the content of open textbooks is up-to-date as well as relevant to students' lives. They perceived that the limited flexibility in the content of standard textbooks might compel students to spend large sums of money for a new edition of a particular book. On the other hand, faculty indicated that accessing up-to-date information at no cost (or low cost for printing) becomes possible through open textbook adoption. At the same time, open textbooks helped faculty to create a learning atmosphere that is relevant and meaningful to students. For instance, a physics instructor highlighted relevancy as one of her major motivations: "There was no specialized textbook for teaching Physics of California and this textbook had a lot of everyday examples."

\section{Repurposing}

In this study, the possibility of adaptation, modification, and customization that open textbooks provide was cited as important to repurposing the content of books 
based on students' learning needs. Open textbooks' ability to be repurposed was one of the critical motivations for $12(24 \%)$ of the 51 study participants. For instance, a communication professor explained, "The major reason for adopting this [open] textbook was to save students money, and to have the ability to customize a rhetoric text to meet the needs of my students." In total, though only $24 \%$ of the faculty members in the study mentioned adaptability as one of their main motivations for choosing to use open textbooks, $39 \%$ (20 out of 51) spoke somewhere within their e-portfolios of the value of being able to customize the text to better fit their courses and students.

\section{Research question 2: What were the cost savings for students when these faculty adopted an open textbook for their courses?}

Most of the faculty in the study (44 out of 51) reported the usual costs for a traditional textbook or other resources for their courses, with the average of these being about $\$ 140$ per student, per course. The typical costs for new textbooks reported by faculty ranged from $\$ 50$ to over $\$ 275$ per book. Fewer faculty members (32) reported how many students they teach per year and thus were able to estimate total cost savings to all students in their courses per year. Of those, the total amount reported saved was $\$ 706,740$ per year, for 5733 students. That's approximately $\$ 123$ per student, per year, for the 32 faculty members who reported annual savings for their students.

\section{Research question 3: What was the attitude of students towards the open textbooks adopted?}

The attitude of students towards open textbooks is an important aspect of their implementation in courses because whether students find them valuable may affect whether faculty decide to adopt them. Thus, faculty gathered feedback from students to find out their views of open textbooks and published leading themes in the students' feedback on their e-portfolios. 40 of the 51 portfolios contained data about students' attitudes towards the open textbooks used in their classes, and Table 3 summarizes this data.

Analysis of the available data revealed that students appreciated most the financial aspects of open textbooks. In fact, primary themes shared on 37 e-portfolios (93\% of those that shared data on student perceptions) were related to how open textbooks help students to avoid exorbitant textbook costs. One sociology faculty quoted a student as saying:

Table 3 Students' attitude towards the open textbooks

\begin{tabular}{lll}
\hline & Positive attitude & Negative attitude \\
\hline Cost saving & $37(97 \%)$ & 0 \\
Content & $17(43 \%)$ & $6(15 \%)$ \\
Accessibility & $16(40 \%)$ & 0 \\
\hline
\end{tabular}

$\mathrm{n}=40$ 
One of the biggest worries I have throughout the semester, is ensuring my transportation expense. I was quite grateful that the book was available for free. This allowed me to worry less about the other parts of my life that interfere with my goal.

Another key benefit perceived by students is the content of the open textbooks. Students' positive feedback regarding attributes of the content, including the quality, relevancy and format, appeared on 17 (43\%) of the 40 faculty e-portfolios that reported student feedback. While the quality and format of the content were represented by the same amount of positive feedback (7), three of the 17 faculty e-portfolios reported that students appreciated the relevancy of the content in the textbooks. More specifically, students considered the quality of the content either the same or superior to traditional textbooks. In regards to format, students appreciated interactive content (e.g. videos, puzzles, calculator) in the open textbooks. Finally, students felt fortunate to be able to engage in real world examples.

Along with financial and content factors, the accessibility of the open textbooks positively influenced students' attitudes towards their implementation. Out of the 40 faculty e-portfolios that reported student feedback, $16(40 \%)$ stated that students appreciated being able to access the open textbooks online or download them on their digital devices for further use at anytime and anywhere. An education student declared his/her contentment related to accessibility of the open textbooks by saying, "I thought that having the textbook online was much more than just saving money. It was nice to just pull it up anywhere without having to bring a big bulky book with me." Even though the majority of students had positive open textbook experiences, $6(15 \%)$ of the e-portfolios reported some negative comments by students in relation to content. Students' comments on two of the digital portfolios had concerns about the lack of relevant content, and four of them drew attention to formatting issues such as readability and lack of visuals.

\section{Research question 4: What impact did the open textbooks have on student learning and retention?}

The numbers of faculty members reporting on the impact of open textbooks on student learning are summarized in Table 4.

For the $55 \%$ of the 51 faculty who assessed the impact of adopting an open textbook on student learning outcomes, all reported that they remained the same or improved. None reported that student learning declined.

Out of the 51 faculty, 20 reported that student learning outcomes had improved as a result of using open textbooks, and nine said they had measured such outcomes by

Table 4 Impact of adopting open textbooks on student learning and retention

\begin{tabular}{lclll}
\hline Question & Yes, improved & Stayed the same & Declined & Not assessed/unsure \\
\hline Student learning improved? & $20(39 \%)$ & $8(16 \%)$ & 0 & $23(45 \%)$ \\
Student retention improved? & $8(16 \%)$ & $6(12 \%)$ & 0 & $37(72 \%)$ \\
\hline
\end{tabular}

$\mathrm{n}=51$ 
looking at data such as improved scores on exams or assignments, or improved course grades overall. Of the rest (11), eight provided no data or explanation to support their claims that student learning had improved with the use of open textbooks, and three provided anecdotal data about how they thought students had improved with no evidence of formal measures such as changes in grades. Among all of the 20 that reported improvement in learning outcomes, only seven provided some explanation for why they thought such improvement occurred (though some mentioned more than one reason). Four said that they thought outcomes had improved due to accessibility of the open textbooks - both because they were free of cost and because they could be accessed in different formats and could be read on multiple devices. According to one faculty member who collected data about the impact of the open textbook on student outcomes in her course, "Students reported having access to a free textbook on multiple devices (i.e., smartphone, laptop, or tablet) encouraged reading and [they] use[d] the text as a tool for note taking or point of reference during class." Four faculty said that student learning may have improved in their courses in part because they redesigned part or all of a course, alongside adopting an open textbook. Three faculty mentioned something about the specific OER used as an explanation for why student learning may have improved; e.g., one faculty member said that watching videos is more engaging that reading text, and another said that the particular open textbook used had examples that were relevant to the students' lives.

Regarding student retention in courses (see Table 4), 37 (72\%) did not assess whether or not it had improved. Of the 14 that did, 8 (16\% of all 51 faculty) said student retention had improved, and 6 (12\% of all 51 faculty) said it remained the same. Four of the faculty who said retention had improved elaborated on their answers. A sociology instructor reported a $2 \%$ increase in retention in her course after adopting an open textbook. A statistics instructor reported that after adopting an open textbook he noticed "a huge increase in retention, especially in the first two to three weeks," because when he used a traditional textbook in the past, it was during the first twothree weeks that some students "realized that they couldn't afford the textbook, and they dropped the class." Another statistics instructor said that retention improved because the open materials emphasized the relevance of the subject to students' lives.

\section{Research question 5: What other benefits and drawbacks did faculty report in adopting open textbooks?}

The other benefits and drawbacks faculty reported are summarized in Table 5.

Table 5 Other benefits or drawbacks reported

\begin{tabular}{lrr}
\hline Question & Yes & No \\
\hline Collaborated more with other faculty? & $31(61 \%)$ & $20(39 \%)$ \\
Used wider range of teaching materials? & $44(86 \%)$ & $7(14 \%)$ \\
Drawbacks to using OER? & $7(14 \%)$ & $44(86 \%)$ \\
\hline
\end{tabular}

$\mathrm{n}=51$ 
Out of the 51 faculty e-portfolios, $31(61 \%)$ said they collaborated more with other faculty as a result of adopting an open textbook, and 24 elaborated on how they did so. Among those, the following were reported:

- Worked with colleagues to revise an open textbook (or other OER) or create a new book derived from the original textbook (mentioned by seven faculty members).

- Worked with other faculty using the same open textbook to create ancillary resources and assignments (mentioned by four faculty members).

- Collaborated with others to create an entirely new open textbook (mentioned by two faculty members).

- Collaborated on redesign of a course after adopting an open textbook (mentioned by one faculty member).

On the question of whether they used a wider range of teaching materials after adopting an open textbook or other OER, a significant majority said they did (86\%), and about half explained their answers. Among those, six faculty members said they used more videos in class as a result of assigning an open textbook, five said they used new homework or study question tools and two said they supplemented the assigned open textbook with other open educational resources. A sociology instructor elaborated on how using an open textbook encouraged her to investigate and use other resources: "Using an open e-text encouraged me to learn and use technology in the classroom including Apps and tools such as Nearpod, Socrative, Poll Everywhere, and SmartSeat. I also started creating instructional videos using a webcam and YouTube."

There were also various other benefits reported, beyond those previously discussed, related to the fact that the open textbooks were available digitally and licensed to allow re-use and re-posting. Three faculty members mentioned the value of being able to embed the text directly into the Learning Management System (LMS) website for the course. One of those stated that it was important to be able to release chapters on the LMS to students at a particular time, rather than providing access from the beginning of the course. One faculty member noted how useful it was to be able to project parts of the textbook on a screen during class. Another stated that it was useful to be able to copy and paste sections of the textbook into emails for students when answering questions.

Just seven of the 51 faculty reported drawbacks to using open textbooks (14\%). Only one stated that the open online resource she adopted for her course (a series of videos rather than a book) was not of adequate quality and that she would not use it again; another stated that the open textbook was "a little dry and suffers from disjointed writing" due to there being multiple authors, but did not say this was a significant enough problem to stop using the textbook. The extra time needed to redesign lectures and assignments for a new textbook was noted by one faculty member, but this would likely happen with the adoption of any new textbook. Two faculty mentioned problems specifically related to e-textbooks. One pointed to connectivity issues: "Students without reliable connectivity may need to plan to use school resources for viewing and/or downloading." Another said that "students began to cut and paste from the digital book into short answer questions on [online] 
quizzes and into papers" without proper citation. However, as she noted, this could be addressed with clearer discussion of proper citation methods.

\section{Discussion}

The 51 e-portfolios from faculty in higher education institutions in California that we examined showed overwhelmingly positive experiences with using open textbooks. Cost savings was the most prominent motivating factor reported by faculty in adopting an open textbook ( $80 \%$ of the e-portfolios), and was the most common benefit noted by students in their feedback ( $73 \%$ of the e-portfolios). On average, based on our data, students saved $\$ 140$ each per course on textbooks, with some faculty reporting cost savings of over $\$ 200$ per student, for their courses.

Over $40 \%$ of faculty pointed to the quality, relevancy and currency of the content of the open textbooks they adopted, with only two of the 51 faculty reporting problems with content. Similarly, over $40 \%$ of the e-portfolios that reported student feedback showed that students had positive attitudes towards the content of the open textbooks, with $15 \%$ of the e-portfolios noting some negative comments by students about content. Finally, nearly $40 \%$ of faculty said that the ability to adapt open textbooks to customize them for particular courses was also as a significant benefit. Students, on the other hand, tended to focus more on accessibility of the textbooks in the sense of being able to easily read them at different times and places, or access them in different formats: of those portfolios with student feedback, $40 \%$ mentioned the value of this form of accessibility.

Adopting open textbooks had positive impacts on students and faculty in other ways as well. In fact, $86 \%$ of faculty reported using a wider range of teaching materials through or as a result of adopting an open textbook, and over $60 \%$ said they collaborated more with other faculty members. Though not all faculty e-portfolios reported assessing the impact of adopting open textbooks on student learning and retention, all of those that did said that these remained the same or improved. A few faculty members did mention drawbacks to open textbooks, but many of these were things that one can experience with traditional, "closed" textbooks as well, such as extra prep time needed to design a course when adopting a new textbook and issues with content and quality.

\section{Limitations and future research}

This study is limited by the relatively small number of e-portfolios provided; moreover, drawing conclusions is also difficult because not all faculty provided the same amount of detail in their e-portfolios. For example, not all faculty gave the number of students who typically enrolled in their courses, which is needed to estimate cost savings per year when combined with the price of the new textbook they had used in the past. We also only have data from faculty reporting on what their students found valuable; while some faculty included direct quotes from students, most data about what students thought of the open textbooks came from summaries of what faculty heard from students. Finally, the data on student 
retention and learning outcomes on these e-portfolios is somewhat sparse, and is not measured in any systematic way for each faculty member.

Since our data analysis was conducted, 21 more faculty e-portfolios have been posted on the Cool $4 \mathrm{Ed}$ website, and as more faculty from California institutions of higher education adopt open textbooks, more e-portfolios may be posted in the future. Our data could be supplemented by similar analyses on this new data. It would be particularly useful to focus on faculty adaptations of open textbooks or other OER; the research literature on OER has little data on the degree to which faculty tend to just use open textbooks and other OER as they find them, or whether they engage in revising those materials to fit their course context (and if so, how). We found that 7 out of the 51 faculty in our study reported that they had revised an open textbook for their course or created a new book derived from an earlier one, and two others said they had created an entirely new textbook. However, there was no area on the e-portfolios for faculty to report on this specifically; the only place faculty mentioned whether they had revised OER is on the section asking about whether they had collaborated more with other faculty or not, as a result of adopting an open textbook or other OER. It's possible that more faculty revised the open materials than we have evidence for on these e-portfolios, and it would be useful to do follow-up surveys or short interviews to find out this information.

\section{Conclusion}

Supported by 2013 legislation in the state of California, many students in California institutions of higher education are able to access open textbooks for their courses, significantly reducing the financial barriers to learning. In 2015, new legislation provided further funding for institutions in the California State University system and the California Community Colleges to develop plans to support faculty in adopting open textbooks and other open educational resources (RFP to open educational resources adoption incentive program 2016). Our study of over 50 portfolios from faculty who have adopted open textbooks in California shows the value of such efforts: the vast majority of instructors and students report positive experiences with these textbooks, supporting the claim that adopting OER can save students a great deal of money while still providing high quality learning materials.

Funding This study was funded by a grant from The William and Flora Hewlett Foundation, awarded through the Open Education Group: http://openedgroup.org/fellowship.

\section{Compliance with ethical standards}

Conflict of interest Ozgur Ozdemir and Christina Hendricks have received research grants from The William and Flora Hewlett Foundation.

Open Access This article is distributed under the terms of the Creative Commons Attribution 4.0 International License (http://creativecommons.org/licenses/by/4.0/), which permits unrestricted use, distribution, and reproduction in any medium, provided you give appropriate credit to the original author(s) and the source, provide a link to the Creative Commons license, and indicate if changes were made. 


\section{References}

Advisory Committee on Student Financial Assistance. (2007). Turn the page: Making college textbooks more affordable (A report of the Advisory Committee on Student Financial Assistance). Retrieved from http://www2.ed.gov/about/bdscomm/list/acsfa/turnthepage.pdf

Allen, N., \& Student PIRGs. (2010). A cover to cover solution: How open textbooks are the path to textbook affordability. Student PIRGs. Retrieved from http://www.studentpirgs.org/sites/student/ files/reports/A-Cover-To-Cover-Solution_4.pdf

Average estimated undergraduate budgets 2015-2016. (2015). Trends in higher education. The College Board. Retrieved from http://trends.collegeboard.org/college-pricing/figures-tables/averageestimated-undergraduate-budgets-2015-16

Bliss, T. J., Robinson, T. J., Hilton, J., \& Wiley, D. A. (2013). An OER COUP: College teacher and student perceptions of open educational resources. Journal of interactive media in education, $O(0)$. Retrieved from http://jime.open.ac.uk/article/view/252

California Open Educational Resources Council. (2016). White paper: OER adoption study (April 1 2016). Retrieved from http://tinyurl.com/WPOERAdoption040116

Cochrane, D., \& Szabo-Kubitz, L. (2016). On the verge: Costs and tradeoffs facing Community College Students [Report]. The Institute for College Access and Success. Retrieved from http://ticas.org/ content/pub/verge

Duties of California OER Council members. (2014). Intersegmental committee of the academic senates. Retrieved from http://icas-ca.org/duties-of-coerc

College costs. (2015). I can afford college.com. California Community Colleges. Retrieved from http:// www.icanaffordcollege.com/en-us/aboutcommunitycolleges/collegecosts.aspx

eTextbook Reviews. (2014). California open online library for education. Retrieved from http:// coolfored.org/reviews.html

Feldstein, A., Martin, M., Hudson, A., Warren, K., Hilton III, J., \& Wiley, D. (2012). Open textbooks and increased student access and outcomes. European Journal of Open, Distance and E-learning, 15(2). Retrieved from http://www.eurodl.org/?p=current\&article\&article=533

Florida Virtual Campus. (2016). 2016 Florida student textbook and course materials survey (Draft). Retrieved from https://florida.theorangegrove.org/og/items/3a65c507-2510-42d7-814cffdefd394b6c/1/

FAQs-costs. (2015). CSU mentor. Retrieved from http://www.csumentor.edu/faq/finaid_costs.asp

Frydenberg, J. \& Matkin, G. (2007). Open textbooks: Why? What? How? When? Proceedings from The William and Flora Hewlett Foundation Open Textbook Meeting, Newport Beach. Retrieved from http://www.hewlett.org/uploads/files/OpenTextbooks.pdf

Hilton III, J. (2016). Open educational resources and college textbook choices: A review of research on efficacy and perceptions. Educational Technology Research and Development, 1(18). Retrieved from http://link.springer.com/article/10.1007/s11423-016-9434-9/fulltext.html

Hilton, J., \& Wiley, D. (2011). Open-access textbooks and financial sustainability: A case study on Flat World Knowledge. The International Review of Research in Open and Distance Learning, 12(5). Retrieved from http://www.irrodl.org/index.php/irrodl/article/view/960/1860

Merriam, S. B. (2009). Qualitative research: A guide to design and implementation: Revised and expanded from qualitative research and case study applications in education. San Francisco, California: Jossey-Bass.

Petrides, L., Jimes, C., Middleton-Detzner, C., Walling, J., \& Weiss, S. (2011). Open textbook adoption and use: Implications for teachers and learners. Open Learning, 26(1), 39-49.

RFP to open educational resources adoption incentive program. (2016). California open online library for education. Retrieved from http://coolfored.org/ab798_rfp.html\#section3

Seidel, K. (2009). Online textbooks deliver timely, real world content. Educause Review, 44(1). Retrieved from http://er.educause.edu/articles/2009/1/online-textbooks-deliver-timely-realworld-content

Student costs. (2016). Facts about the CSU. Retrieved from http://www.calstate.edu/csufacts/2016Facts/ costs.shtml

Student PIRGs. (2015). Open textbooks: The billion-dollar solution. Washington, DC: Ethan Senack. Retrieved from http://www.studentpirgs.org/sites/student/files/reports/The\%20Billion\%20Dollar\% 20Solution.pdf 
Student PIRGs. (2014). Fixing the broken textbook market: How student respond to high textbook costs and demand alternatives. Washington, DC: Ethan Senack. Retrieved from http://www.studentpirgs. org/sites/student/files/reports/NATIONAL\%20Fixing\%20Broken\%20Textbooks\%20Report1.pdf

UC's affordability report. (2015). The University of California System Information Center. Retrieved from http://www.ucop.edu/institutional-research-academic-planning/_files/affordability_at_uc.pdf

UC quick facts at a glance. (2015). The University of California System Information Center. Retrieved from http://www.universityofcalifornia.edu/infocenter/uc-quick-facts-glance

UC remains affordable for undergraduates. (2015). The University of California System Information Center. Retrieved from http://www.universityofcalifornia.edu/infocenter/uc-remains-affordableundergraduates

Wiley, D., \& Green, C. (2012). Why openness in education? In D. G. Oblinger (Ed.), Game changers: Education and information technologies. Educause. Retrieved from https://library.educause.edu/ resources/2012/5/chapter-6-why-openness-in-education

Ozgur Ozdemir holds Bachelor's and Master's Degree in instructional technology. He is a Ph.D. candidate in the department of Instructional Systems Technology at Indiana University. His research interests include open education, open educational resources and open textbooks.

Christina Hendricks is a Professor of Teaching in Philosophy at the University of British ColumbiaVancouver. Her research interests include the Scholarship of Teaching and Learning (particularly focusing on peer feedback on writing) and open education, including the use and creation of open educational resources and open textbooks. 